\title{
THE SNOWMELT PERIOD IN A MEDITERRANEAN HIGH MOUNTAIN CATCHMENT: RUNOFF AND SEDIMENT TRANSPORT
}

\author{
N. LANA-RENAULT ${ }^{(1,2)}$, B. ALVERA ${ }^{(3)}$ \\ J. M. GARCÍA-RUIZ(2) \\ (1) Department of Physical Geography, Utrech University, \\ Faculty of Geosciences, P.O. Box 80115, The Netherlands \\ (2) Instituto Pirenaico de Ecología, CSIC, \\ Campus de Aula Dei, Apartado 13034, 50080-Zaragoza, Spain \\ (3) Instituto Pirenaico de Ecología, CSIC, \\ P.O. Box 64, 22700-Jaca (Huesca), Spain \\ Correo electrónico de contacto: lana-renault@geo.uu.nl
}

\begin{abstract}
Runoff and sediment transport during the snowmelt period (MayJune, 2004) in the Izas catchment (Central Pyrenees) were studied to obtain a sediment balance and to assess the relative importance of sediment transport during that period. The results demonstrated the importance of the snowmelt period and showed that most sediment was exported in the form of solutes $176 \%$ of the total for the May-June time span); 24\% was exported as suspended sediment and no bedload was recorded. Suspended sediment mostly occurred during the second phase of the snowmelt period, when an expanding area of the catchment was free of snow. Sediment transport during the snowmelt period represented $43 \%$ of the annual sediment yield.
\end{abstract}

RESUMEN. Se ha estudiado el transporte de sedimento y la escorrentía durante el período de fusión de nieve (mayo-junio de 2004) en la cuenca experimental de Izas (Pirineo Central), con el fin de (i) obtener balance de sedimento y (ii) evaluar la importancia relativa del período de fusión en el transporte total de sedimento a lo largo del año. Los resultados demuestran, por un lado, la importancia hidromorfológica del período de fusión y, por otro, que la mayor parte del sedimento fue exportado en forma de solutos (76\% del total durante el período de mayo a junio); el sedimento en suspensión representó el 24\%; finalmente, no se registró transporte de carga de fondo. El sedimento en suspensión fue principalmente movilizado durante la segunda parte del período de fusión, cuando una creciente superficie de la cuenca estaba ya libre de nieve. El transporte de sedimento durante el período de fusión de nieve representó el $43 \%$ de la producción anual de sedimento. 
Palabras clave: cuenca experimental, alta montaña, sedimento en suspensión, solutos, Pirineo español.

Key words: experimental catchment, high mountain, suspended sediment, solutes, Spanish Pyrenees.

Enviado el 16 de noviembre de 2009

Aceptado el 3 de marzo de 2010

\section{Introduction}

Snow accumulation and melting play key hydrological roles in high mountain catchments of temperate regions, controlling in part the seasonality of floods, the spatial organization of soil saturation processes and overland flow, the intensity of high flows, and the constant low winter discharges (Soulsby et al., 1997; García-Ruiz et al., 2001; López-Moreno and García-Ruiz, 2004). This is particularly important in Mediterranean basins, where most of discharge is generated in mountain areas, and where water management is based on reservoirs that largely depend on high flows generated during the snowmelt period (López-Moreno et al., 2004). The snowmelt period also plays a very important geomorphological role, resulting in shallow landsliding, solifluction, rilling and sheet wash erosion (Barsch and Caine, 1984; García-Ruiz et al., 1990).

Monitoring of the Izas catchment (in the sub-Alpine belt of the Central Spanish Pyrenees) since 1987 has provided information on various hydrological and sediment transport processes in a high mountain environment (Martínez-Castroviejo et al. 1991; Del Barrio et al., 1997; Alvera and García-Ruiz, 2000; Anderton et al., 2002). In this study runoff and sediment transport was investigated during the snowmelt period to analyze the effect of both daily and seasonal hydrological contrasts on sediment mobilization and export.

\section{The study area}

The Izas catchment $\left(0.33 \mathrm{~km}^{2}\right)$ is located in the Upper Gállego River valley, Central Spanish Pyrenees, between 2060 and $2280 \mathrm{~m}$ a.s.1. The bedrock is composed of densely fractured carboniferous slate. Solifluction is very active in deep soils (Del Barrio and Puigdefábregas, 1987), while terracettes develop on degraded soils of south facing slopes, although they do not seem to contribute sediment because, in general, they are disconnected from the fluvial system (Figs. 1 and 2). A dense and steep gully system occurs on slates close to the divide (Fig. 3). This small area (5\% of the total catchment) is the most important sediment source for the main channel (Díez et al., 1988). 


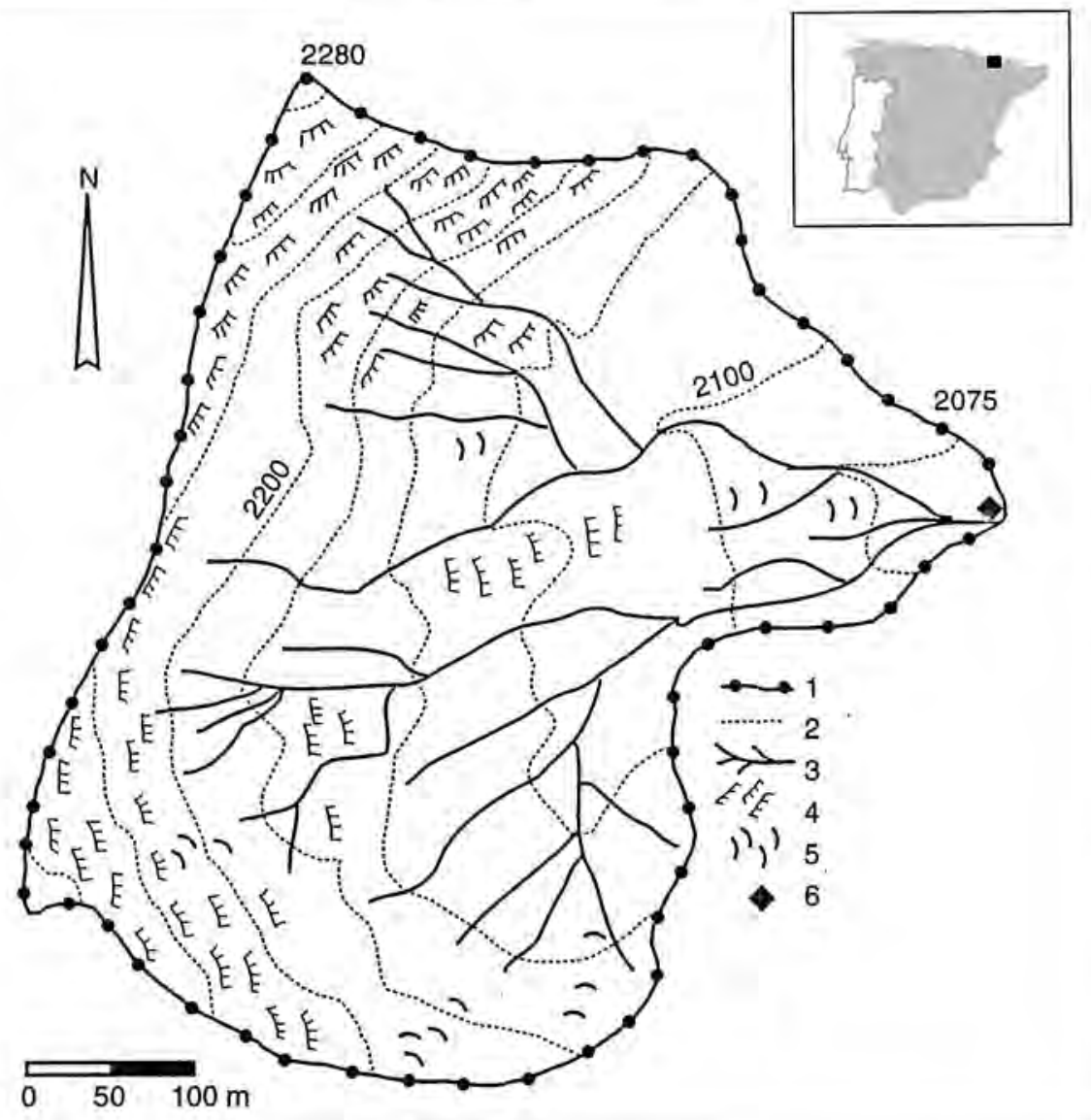

Figure 1. The study area and its geomorphic features.

Mean annual temperature is around $4^{\circ} \mathrm{C}$ and total annual precipitation is about 2000 $\mathrm{mm}$, with most precipitation occurring between October and May. During the cold season, precipitation falls as snow, which covers the catchment until June. Sub-alpine and alpine grasslands (Festuca eskia, Nardus stricta) cover most of the slopes (Fig. 4).

\section{Equipment and Methods}

The Izas catchment is equipped with a gauging station (V-notch weir), with a pressure transducer and a thermistor recording the height and temperature of runoff water, respectively. Sediment and dissolved solid concentrations are obtained using an automatic water sampler, active during the high flow periods, a conductivimeter, and a turbidimeter that enabled evaluation of the solute and suspended sediment concentration 


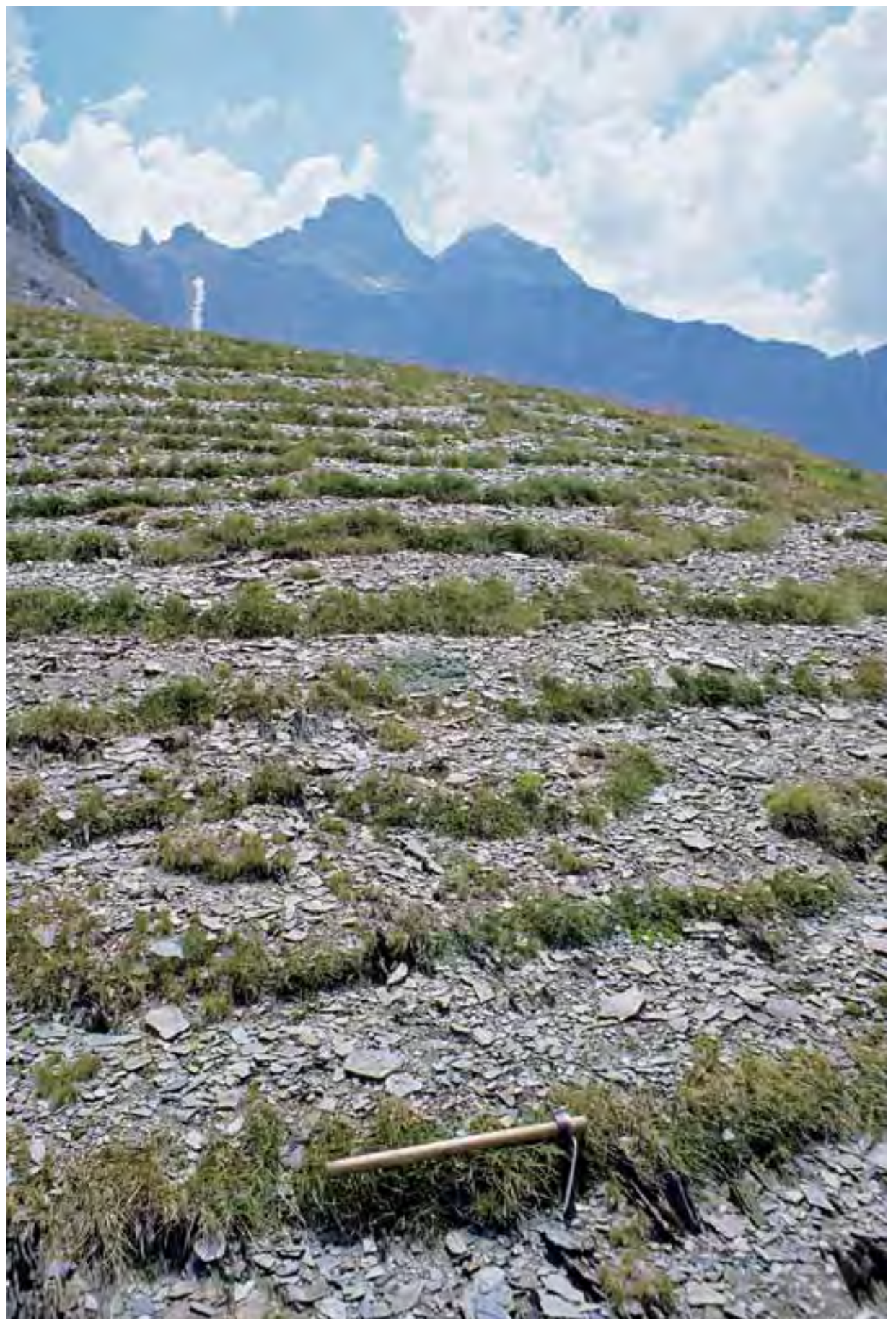

Figure 2. Terracettes in a steep slope of the Izas catchment. 


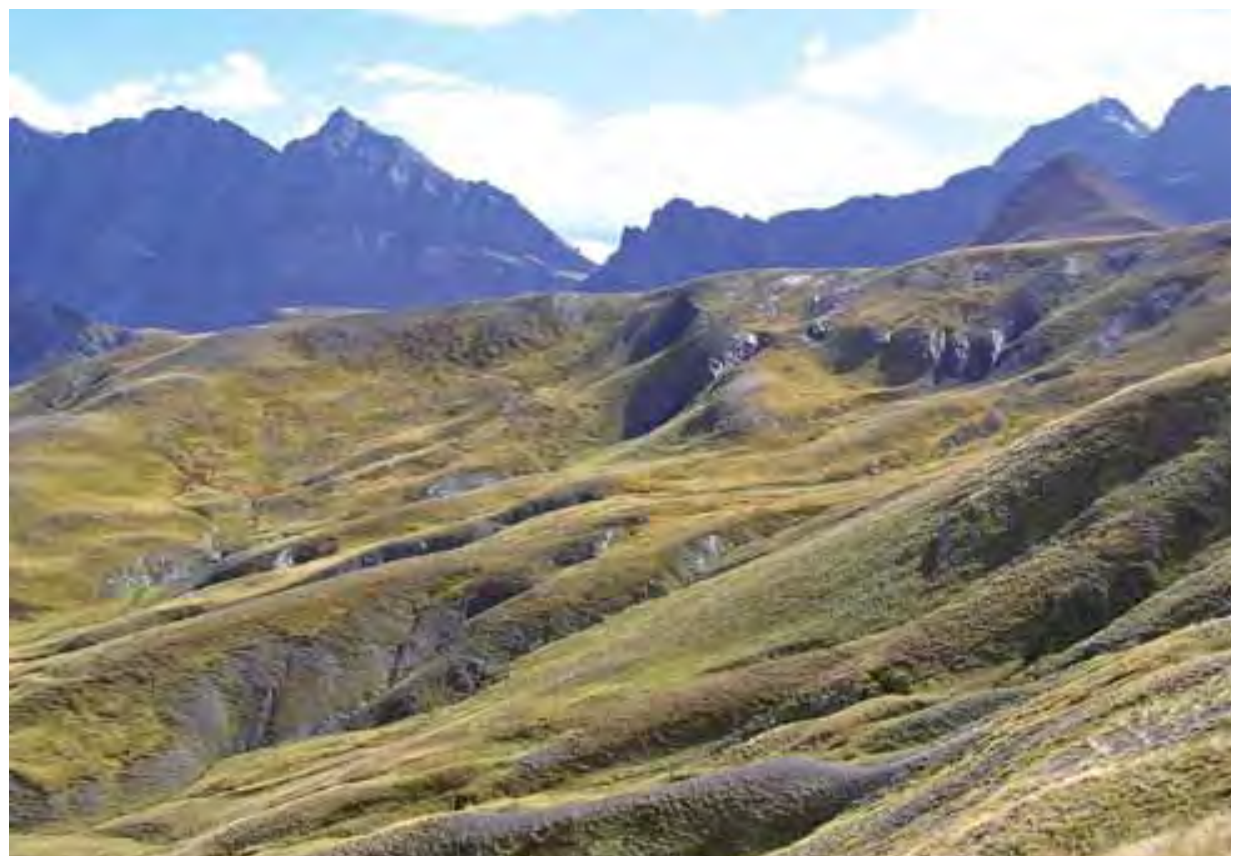

Figure 3. The headwater of the Izas catchment, showing the dense gully network on carboniferous slates.

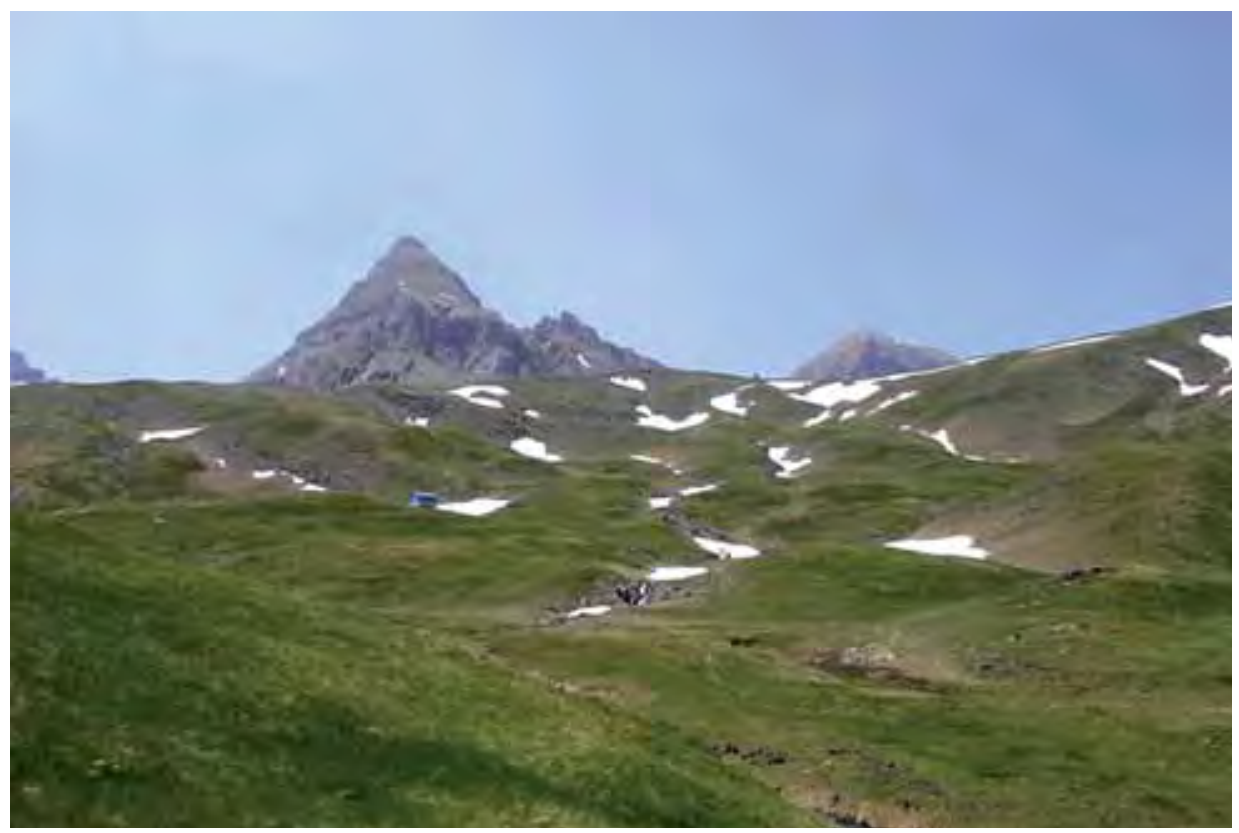

Figure 4. General perspective of the Izas catchment, with alpine and sub-alpine grasslands. 
after calibration. Bedload transport was monitored with a slot-trap located in the stream bed. Periodically, in particular after heavy rainstorms and at the end of the snowmelt period, the trap was emptied and the volume of sediment weighted. An automatic weather station recorded information on air temperature, the relative humidity of air, radiation, the velocity and direction of wind, and precipitation. Information on the snowpack corresponds to an ultrasonic ranging sensor and a snow pillow located close to the flume, at the lowest end of the catchment, where snowmelt ends rapidly compared to the rest of the catchment. Hydrological and sediment transport information for the water year 2003/04 was used for this study. A sediment balance was performed to estimate the relative importance of solutes, suspended sediment and bedload yield during the snowmelt period and for the whole year.

\section{Results}

Figure 5 shows the evolution of daily precipitation, average daily discharge, suspended sediment concentration, and snowpack depth for the water year 2003/04. The figure shows a period of increasing snow accumulation from the end of October to April. Nevertheless, the falling section of the curve does not represent the behavior of the whole catchment, because snowmelt ends earlier at the position of the snow pillow than in the rest of the catchment.

A maximum snow accumulation of about $1.5 \mathrm{~m}$ was recorded at the beginning of April. Increases in snow accumulation were directly related to the major snowfalls events. Periodic visits to the catchment enabled temporal estimates of the snow-covered area: 99\% (14 May), 90\% (25 May), 60\% (3 June), 50\% (10 June), 40\% (17 June), 10\% (23 June) and $1 \%$ (8 July). The evolution of discharge showed (i) large fluctuations in autumn, corresponding to rainfall events accompanied by short snowmelt periods (such as occurred at the end of November); (ii) a long period in winter mainly characterized by low flows, with almost constant discharges in February and March; and (iii) a very significant period of high flows between the end of April and the end of June, coinciding with snow depletion in the catchment. It was notable that the suspended sediment concentration showed small peaks in autumn and during the snowmelt period.

Figure 6 shows the discharge and suspended sediment concentration during the snowmelt period, during which typical daily pulses are evident. The snowmelt period was characterized by a marked discharge increase after 11 May, and a sustained period of continuous high flows between mid May and mid June. Daily hydrographs showed a characteristic wave pattern (Alvera and Puigdefábregas, 1985) reflecting the effect of daily temperature oscillations. These waves remained throughout the second half of June, when the presence of snow was increasingly spatially-limited, with a declining intensity of the daily peak flows. Some peak flows related to greater increases in temperature were recorded, occasionally accompanied by rainfall events. The maximum discharge was registered on 7 June, when a temperature increase of $10^{\circ} \mathrm{C}$ and a $19 \mathrm{~mm}$ rainfall produced a peak flow of $336 \mathrm{~s}^{-1}$. The suspended sediment concentration did not follow exactly this daily pattern, with the exception of some days in mid June that 


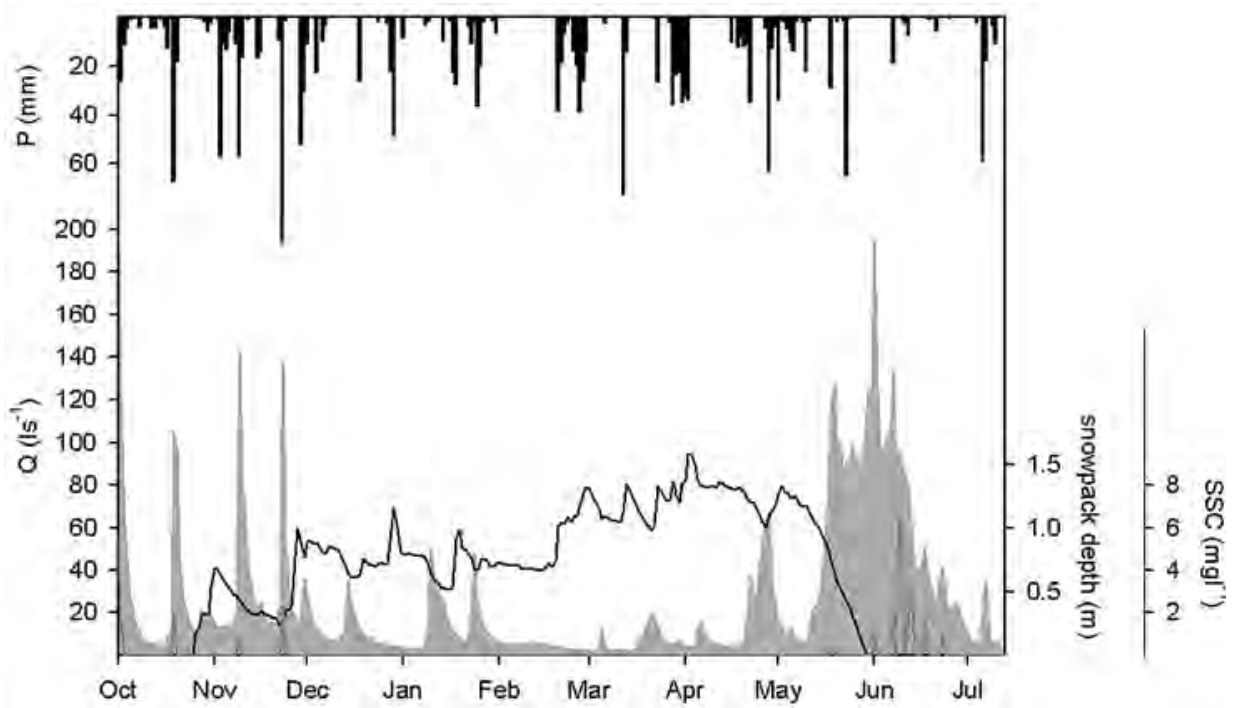

Figure 5. Daily precipitation $(P)$, average daily discharge $(Q)$, suspended sediment concentration (SSC) and snowpack depth for the period 1 October 2003 to 12 July 2004.

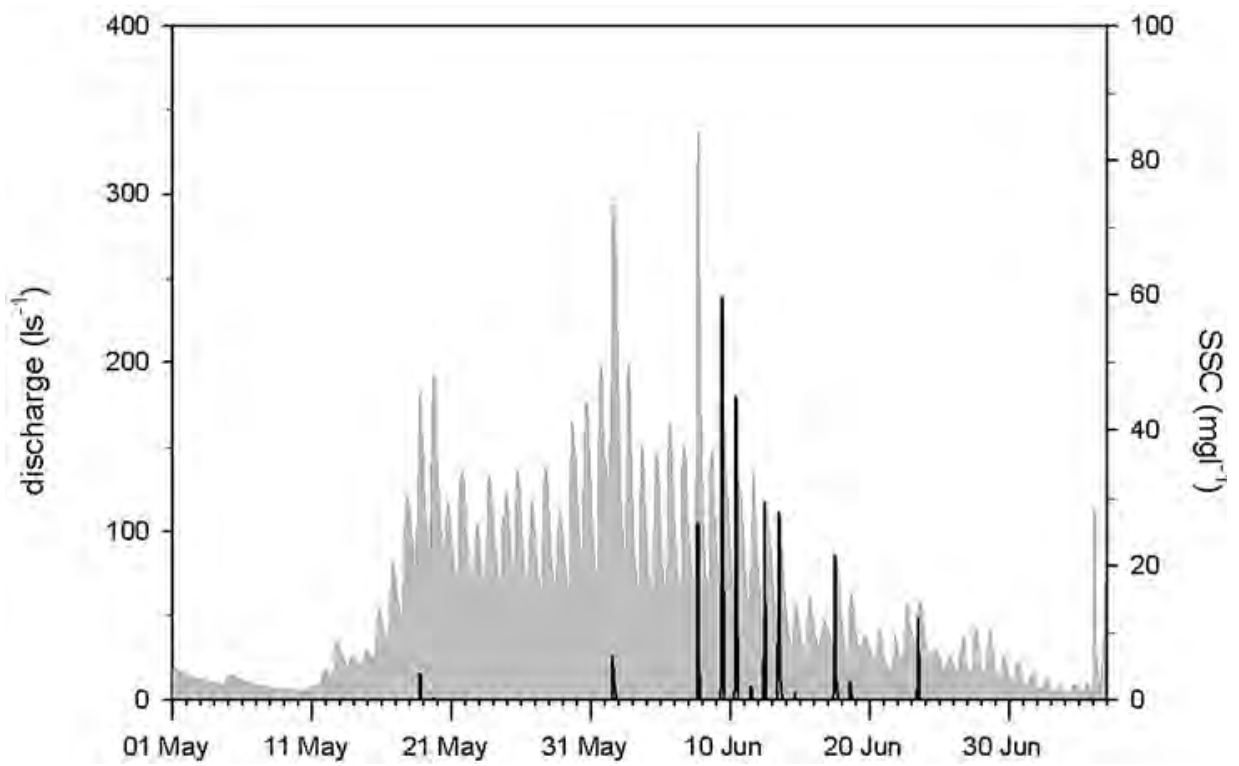

Figure 6. Hourly discharge and suspended sediment concentration (SSC) during the snowmelt period. 
coincided with some high discharges. It is interesting to note that suspended sediment mostly occurred during the second phase of the snowmelt period, when an expanding area of the catchment was free of snow.

Table 1 shows sediment exports during the snowmelt period and over the whole year. Whereas precipitation during the snowmelt period was $11 \%$ of the annual amount, runoff was $48 \%$ (a consequence of previous snow accumulation), suspended sediment was $61 \%$, and solutes were $41 \%$. If the snowmelt period is considered in isolation, sediment transport was dominated by solutes $(76 \%)$ followed by suspended sediment (24\%). During the two-month snowmelt period, suspended sediment and solute outputs indicate an erosion rate of $90.2 \mathrm{Mg} \mathrm{km}^{-2}$ or $43 \%$ of the annual yield. No bedload was recorded during the snowmelt period but $9.3 \mathrm{Mg} \mathrm{km}^{-2}$ was recorded during the rest of the year, which is a typical figure for the Izas catchment (Alvera and García-Ruiz, 2000). Sediment outputs at annual basis represented an erosion rate of $210.9 \mathrm{Mg} \mathrm{km}^{-2}$ $\mathrm{yr}^{-1}$, which is consistent with the annual sediment yield estimated for the Izas catchment since 1987 (200-320 Mg km-2 $\mathrm{yr}^{-1}$; Alvera and García-Ruiz, 2000). According to previous papers (Díez et al., 1988), the main sediment source was the channel itself and a dense gully network in the headwater. Periglacial terracettes did not contribute with sediment to the channel, even if they are scarcely protected by the plant cover, neither shallow landslides, which were not connected to the fluvial network.

Table 1. Outputs from the Izas catchment during the snowmelt period and overall for the year 2003/04.

\begin{tabular}{|l|c|c|c|}
\hline & $\begin{array}{c}\text { Water year } \\
\mathbf{2 0 0 3 / 0 4}\end{array}$ & $\begin{array}{c}\text { Snowmelt } \\
\text { period }\end{array}$ & $\begin{array}{c}\text { \% Snowmelt } \\
\text { period }\end{array}$ \\
\hline Precipitation $(\mathrm{mm})$ & 2155 & 228 & 11 \\
\hline Runoff $(\mathrm{mm})$ & 1983 & 955 & 48 \\
\hline Suspended sediment $\left(\mathrm{Mg} \mathrm{km}^{-2}\right)$ & 36.1 & 22.0 & 61 \\
\hline Solutes $\left(\mathrm{Mg} \mathrm{km}^{-2}\right)$ & 161.5 & 68.2 & 41 \\
\hline Bedload $\left(\mathrm{Mg} \mathrm{km}^{-2}\right)$ & 9.3 & 0 & 0 \\
\hline Total sediment $\left(\mathrm{Mg} \mathrm{km}^{-2}\right)$ & 210.9 & 90.2 & 43 \\
\hline
\end{tabular}

\section{Discussion and conclusions}

Sediment transport in high mountain catchments is partially conditioned by snowmelt accumulation and melting periods. Almost no fluctuations occur in sediment transport and discharge during the cold season. The snowmelt period represents a major increase in discharges and daily discharge pulses, due to both seasonal and daily temperature increases. During the water year 2003/04, the discharge during the two- 
month snowmelt period represented almost $50 \%$ of the total annual runoff, and sediment transport (the sum of suspended sediment and solutes) was $43 \%$. These figures indicate the hydrological and geomorphological importance of this brief period during the year. It is also notable that: (i) bedload was not detected during the snowmelt season, suggesting that the daily pulses in discharge were of insufficient energy to move coarse sediments (Alvera and García-Ruiz, 2000), and (ii) most of the suspended sediment was carried in the second part of the snowmelt period, when an expanding area of the catchment was free of snow. This reflects the importance of sediment mobilization from the ravine banks and saturated areas close to the snowmelt front. During the snowmelt period, most sediment was exported in the form of solutes $(76 \%)$, followed by suspended sediment $(24 \%)$. The predominance of solutes has been attributed to the high weathering rate of slate (NadalRomero et al., in press) and to the importance of infiltration during the snowmelt period

Erosion rates determined for the water year 2003/04 were within the long-term typical values for the Izas catchment. For high mountain catchments, few balances have been estimated due to difficulties for monitoring. Besides, the variety of high mountain environments (altitude, aspect, gradient, bedrock and, particularly, connectivity between snow avalanches and the stream) impedes adequate comparisons in most of cases. The values obtained for the Torlesse catchment, New Zealand, are about $30 \mathrm{Mg} \mathrm{km}^{-2} \mathrm{yr}^{-1}$ (Hayward, 1980). Similarly, from the Iron Crag catchment, in northern England, sediment yield was estimated around $45 \mathrm{Mg} \mathrm{km}^{-2} \mathrm{yr}^{-1}$ (Evans and Warburton, 2005). These values are somewhat lower than those from the Izas catchment, what could be due to the location and connectivity of sediment sources, as well as the type bedrock outcrops. This suggests the need for a detailed analysis of prevailing geomorphic processes and sediment accessibility from the hillslopes.

\section{Acknowledgements}

Support for this research was provided by the following projects: "Processes and sediment balances at different spatial scales in Mediterranean environments: Effects of climate fluctuations and land use changes, PROBASE (CGL2006-11619/HID CONSOLIDER), financed by the Spanish Ministry of Science and Technology, and "Assessing climatic change and impacts on the quantity and quality of water, ACQWA" (FP7-ENV-2007-1-212250), financed by the European Commission. Monitoring of the Izas catchment was supported by an agreement between the CSIC and the Spanish Ministry of Environment. The first author benefited from a research contract (I+D+I 20082011 National Program), funded by the Spanish Ministry of Science and Technology.

\section{References}

Alvera, B., Puigdefábregas, J. (1985). Pulsación diaria de la carga suspendida y disuelta en la escorrentía de fusión nival. Cuadernos de Investigación Geográfica, 11: 5-20.

Alvera, B., García-Ruiz, J. M. (2000). Variability of sediment yield from a high mountain catchment, Central Spanish Pyrenees. Arctic, Antarctic and Alpine Research, 32 (4): 478-484. 
Anderton, S. P., White, S. M., Alvera, B. (2002). Micro-scale spatial variability and the timing of snow melt runoff in a high mountain catchment. Journal of Hydrology, 268: 158-176.

Barsch, D., CAine, N. (1984). The nature of mountain geomorphology. Mountain Research and Development, 4: 287-298.

Del Barrio, G., Puigdefábregas, J. (1987). Mass wasting features above the timberline in the Central Pyrenees and their topographic controls. Pirineos, 130: 3-25.

Del Barrio, G., Alvera, B., Puigdefábregas, J., Díez, J. C. (1997). Response of high mountain landscape to topographic variables: Central Pyrenees. Landscape Ecology, 12: $95-115$

Díez, J. C., Alvera, B., Puigdefábregas, J., Gallart, F. (1988). Assessing sediment sources in a small drainage basin above timberline in the Pyrenees. IAHS Publ., 174: $197-205$.

Evans, J., WARBURTON, J. (2005). Sediment budget for an eroding peat-moorland catchment in northern England. Earth Surface Processes and Landforms, 30: 557-577.

García-Ruiz, J. M., Alvera, B., Del Barrio, G., Puigdefábregas, J. (1990). Geomorphic processes above the timberline in the Spanish Pyrennes. Mountain Research and Development, 10(3): 201-214.

García-Ruiz, J. M., Beguería, S., López-Moreno, J. I., Lorente, A., Seeger, M. (2001). Los recursos hídricos superficiales del Alto Aragón y su evolución reciente. Geoforma Ediciones, 192 pp., Logroño.

HAYWARD, J. A. (1980). Hydrology and stream sediment from Torlesse stream catchment. Tussock Grasslands and Mountain Lands Institute, 235 pp., Canterbury, N. Z.

LóPEZ-MoRENO, J. I., GARCÍA-RUIZ, J. M. (2004). Influence of snow accumulation and snowmelt on streamflow in the Central Spanish Pyrenees. Hydrological Sciences Journal, 49 (5): 787-802.

López Moreno, J. I., Beguería, S., García-Ruiz, J. M. (2004). The management of a large Mediterranean reservoir: storage regimes of the Yesa reservoir, Upper Aragón River basin, Central Spanish Pyrenees. Environmental Management, 34 (4): 508-515.

Martínez-Castroviejo, R., García-Ruiz, J. M., Díez, J. C., Alvera, B. (1991). Coarse sediment transport in an experimental high mountain catchment of Central Pyrenees, Spain. Zeitschrift für Geomorphologie Suppl Bd, 83: 105-114.

Nadal-Romero, E., Lana-Renault, N., Serrano-Muela, P., Regües, D., Alvera, B., García-Ruiz, J. M. (in press). Sediment balance in four small catchments with different land cover in the Central Pyrenees. Zeitschrift für Geomorphologie.

Soulsby, C., Helliwell, R. C., Ferrier, R. C., Jenkins, A., Harriman, R. (1997). Seasonal snowpack influence on the hydrology of a sub-arctic catchment in Scotland. Journal of Hydrology, 192 (1-4): 17-32. 